\title{
Penerapan Sistem Olah Tanah dan Pemulsaan Pada Tebu untuk Pengendalian Nematoda Parasit Tumbuhan Dominan
}

\section{Application of Tillage and Mulching Systems on Sugarcane to Control the Dominant Plant Parasitic Nematodes}

\author{
I G. Swibawa ${ }^{1}$, S. P. Yulistiara ${ }^{2}$ dan T.N. Aeny ${ }^{1}$ \\ ${ }^{1}$ Dosen Jurusan Agroteknologi, Fakultas Pertanian Universitas Lampung, \\ ${ }^{2}$ Alumni Jurusan Agroteknologi, Fakultas Pertanian Universitas Lampung, \\ Jln. Prof. Soemantri Brodjonegoro No.1, Bandar Lampung 35145 \\ Korespondensi igswibawa@yahoo.com)
}

\begin{abstract}
Conventional tillage system practices for a long time can reduce soil qualities because of soil erosion, soil compaction and depleting of soil organic matter. Conservation tillage such as No-tillage system can be applied as an alternative technique to rehabilitate soil degradation problems.. This research is a part of a long term study of soil rehabilitation that was conducted from 2010 till now, in PT GMP, Central Lampung. Sampling of nematodes was done on April 2013 when the second ratoon RGM 00-838 variety of sugarcane was 9 months old. The aim of this research was to study the effect of tillage and mulching systems on the abundance of several dominant plant parasitic nematodes. Split plot experimental design was applied on this research. Tillage system as the main plots consisted of intensive tillage and no- tillage systems, while mulching system as the sub-plots consisted of no-mulch and mulching with 80 ton $\mathrm{ha}^{-1}$ of fresh bagasee. Nematodes were collected from $0-20 \mathrm{~cm}$ deep of soil and extracted by sieving and centrifugation with sugar solution methods at the Plant Pest and Disease Laboratory, University of Lampung. The results of this research showed that there were eleven plant parasitic and seven free-living nematode genera inhabited the PT GMP sugarcane plantation. The three plant parasitic nematode genera dominant were Hoplolaimus, Xiphinema, and Hemicriconemoides. No-tillage system effectively reduce the abundance of Xiphinema and, mulching with bagasse reduced the abundance of Hemicriconemoides. Meanwhile, mulching on No-tillage system more effective to reducing the abundance of Hoplolaimus compared to intensive tillage system. This results suggested that the No-tillage with bagasse mulching system was one of alternative techniques to control plant parasitic nematodes pest of sugarcane plantation.
\end{abstract}

Keywords : Tillage, mulching, sugarcane, plant parasitic nematodes, abundance.

Diterima: 10-11-2014 disetujui 07-02-2015

\section{PENDAHULUAN}

Sistem pengolahan tanah intensif dalam jangka panjang dapat menyebabkan penurunan kesuburan tanah dan penurunan produksi tanaman. Kerusakan tanah terjadi karena erosi dan 
I G. Swibawa dkk: Penerapan Sistem Olah Tanah dan Pemulsaan Pada Tebu untuk Pengendalian Nematoda

penurunan kandungan bahan organik tanah. Ada indikasi bahwa fenomena ini terjadi di lahan perkebunan PT Gunung Madu Plantation karena pengolahan tanah intensif yang telah berlangsung selama lebih dari 25 tahun. Upaya untuk meningkatkan produksi tanaman tebu melalui penambahan pupuk anorganik dan pupuk organik di perkebunan ini tidak menunjukkan hasil yang signifikan. Data produksi tebu di perkebunan ini dari tahun 1985 sampai dengan tahun 2005 menunjukkan terjadinya fluktuasi dan cenderung menurun. Untuk mengatasi masalah tersebut dilakukan studi rahabilitasi tanah yaitu penerapan sistem Tanpa Olah Tanah (TOT) dengan pemulsaan menggunakan bagasse. Penggunaan bagasse sebagai mulsa pada pertanaman tebu sangat baik kerena bagasee merupakan limbah pabrik gula yang dihasilkan tiap tahun sangat banyak di PT GMP. Menurut Saechu (2009) pada umumnya pabrik gula memproduksi bagasse sebagai hasil samping sebanyak 27-38\% dari tebu yang digiling.

Sistem olah tanah konservasi yang diantaranya adalah sistem TOT dengan pemulsaan dapat mempertahankan kesuburan tanah. Dalam sistem ini, gangguan terhadap tanah dapat diminimalkan, proses penggemburan tanah dapat terjadi secara alami karena aktivitas penetrasi akar, mikroorganisme, cacing tanah, dan biota tanah lainnya. Utomo et al. (2010) melaporkan bahwa penerapan sistem olah tanah konservasi memberikan pengaruh signifikan karena dapat meningkatkan kelimpahan cacing tanah sampai $252 \%$, biomassa mikroba $70 \%$, dan kandungan C-organik tanah sebesar 13,0\%, apabila dibandingkan dengan sistem olah tanah konvensional. Mulsa dari sisa tanaman yang diberikan dalam sistem TOT menjadi sumber C-organik dan sumber nutrisi bagi mikroorganisme dan biota tanah lainnya. Selain itu, mulsa juga berfungsi untuk menjaga stabilitas suhu dan kadar air tanah sehingga cocok bagi aktivitas biota tanah termasuk nematoda.

Nematoda parasit tumbuhan merupakan salah satu organisme pengganggu tanaman (OPT) penting pada pertanaman tebu. Cadet and Spaull (2005) menyebutkan bahwa lebih dari 310 spesies nematoda parasit tumbuhan yang tergolong dalam 48 genus berasosiasi dengan pertanaman tebu. Genus Pratylenchus, Xiphinema Meloidogyne, Pratylenchus, Scutellonema, Helicotylenchus, Mesocriconema, dan Tyelnchorynchus merupakan genus yang paling sering sebagai OPT penting tanaman tebu (Spaull and Cadet, 2003; Bond, McGawely and Hoy, 2004; Shoko and Zou, 2009; Steven, Sunday and Fisayo, 2014). Di India, nematoda parasit tumbuhan yang sering menyerang tebu adalah Meloidogyne, Pratylenchus, Radopholus, Trichodorus, Rotylenchus dan Rotylenchulus (Prakash, Singh and Kumar, 2009). Sementara itu, Kalshoven (1981) menyebutkan bahwa Pratylenchus, Radopholus, Hirschmaniella, dan Rotylenchulus merupakan nematoda penting pada pertanaman tebu di Indonesia.

Serangan nematoda parasit tumbuhan dapat menimbulkan kerugian yang serius. Di Afrika Selatan, serangan nematoda menyebabkan kehilangan hasil sekitar 1,6 juta ton tiap tahun (Spaul and Cadet, 2003), sementara di Kenya, produksi tebu turun dari 80,86 ton $\mathrm{ha}^{-1}$ pada tahun 1996 menjadi 71,46 ton $\mathrm{ha}^{-1}$ pada tahun 2005 karena gangguan nematoda parasit tumbuhan (Chirchir, Kimenju and Olubayo, 2008). Suatu jenis nematoda parasit tumbuhan dapat menjadi OPT penting karena dalam komunitasnya populasi nematoda tersebut tinggi dan dominan.

Nematoda tergolong biota tanah yang sangat peka terhadap gangguan lingkungan (Freckman dan Ettema, 1993). Oleh karena itu, penerapan sistem pengolahan tanah dengan pemulsaan dapat mempengaruhi aktivitasnya. Beberapa studi mengenai hal ini menunjukkan hasil yang bervarisasi. Penelitian penerapan tanpa olah tanah yang telah berlangsung selama enam tahun yang dilakukan Okada dan Harada (2007) di Jepang menunjukkan bahwa sistem ini mempengaruhi kelimpahan seluruh nematoda, beberapa kelompok makan nematoda dan nematoda OPT kedelai Meloidogyne, tetapi tidak terhadap Pratylenchus yang juga OPT penting kedelai di Jepang. Swibawa (2010) 
melaporkan sistem tanpa olah tanah dan olah tanah minimum yang telah berlangsung selama 23 tahun untuk pertanaman jagung dan palawija lainnya tidak mempengaruhi kelimphan semua kelompok makan nematoda, kecuali nematoda predator. Sibagariang, Swibawa dan Solikhin (2014) melaporkan bahwa penerapan sistem tanpa olah tanah dengan pemulsaan pada pertanaman tebu plant cane umur 11 bulan di PT GMP Lapung dapat meningkatkan kelimpahan beberapa genus nematoda parasit tumbuhan. Hasanah, Swibawa dan Aeny (2014) juga melaporkan bahwa sistem olah tanah dan pemulsaan pada pertanaman tebu ratoon I tidak mempengaruhi kelimpahan nematoda parasit tumbuhan, tetapi mempengaruhi keragaman nematoda, yang dinyatakan dengan indeks Simpsons. Penelitian ini bertujuan untuk mempelajari pengaruh penerapan sistem tanpa olah tanah dan pemulsaan pada pertanaman tebu terhadap populasi nematoda parasit tumbuhan yang dominan pada tanaman tebu periode ratoon-II.

\section{METODE}

Penelitian ini merupakan bagian dari "Studi Rehabilitasi Tanah" jangka panjang yang diselenggarakan atas kerjasama Universitas Lampung, Yokohama National University Jepang, dan PT Gunung Madu Plantations, (Unila-YNU- PT GMP), yang dilaksanakan di lahan PT GMP. Penelitian telah dimulai sejak tahun 2010 pada lahan seluas 2 ha dengan petak satuan percobaan berukuran $25 \mathrm{~m}$ x 40 m yang ditanami tebu varietas RGM 00-838. Pengamatan nematoda dilakukan ketika tanaman tebu ratoon II berumur 9 bulan, yaitu setelah pemanenan tebu ratoon I pada bulan Agustus 2012. Ekstraksi dan identifikasi nematoda dilakukan di Laboratorium Hama dan Penyakit Tubuhan Fakultas Pertanian, Universitas Lampung yang berlangsung bulan April-November 2013.

Percobaan menggunakan rancangan percobaan petak terbagi (split plot experimental design) dengan 5 kelompok sebagai ulangan. Petak utama adalah sistem olah tanah dan pemulsaan sebagai anak petak. Perlakukan sistem olah tanah meliputi olah tanah intensif dan tanpa olah tanah, sedangkan pemulsaan meliputi tanpa mulsa dan pemberian mulsa bagas 80 ton ha ${ }^{-1}$. Pemberian mulsa dilakukan dengan menaburkan bagas secara merata di permukaan tanah, petak yang diberi perlakuan mulsa dipilih secara acak baik pada petak olah tanah intensif maupun pada petak tanpa olah tanah.

Pada setiap petak percobaan, sampel tanah diambil mengikuti metode sampling nematoda menurut standar CSM-BGBD Project. Tanah diambil dari 12 titik sub-sampel yang berposisi pada dua lingkaran yaitu 4 titik pada lingkaran kecil dan 8 titik pada lingkaran besar yang berturutan berjarak 3 $\mathrm{m}$ dan $6 \mathrm{~m}$ dari monolith sebagai pusatnya (Susilo dan Karyanto, 2005). Pada setiap titik sub-sampel tanah diambil pada kedalaman 0-20 cm menggunakan bor tanah, kemudian dikomposit, dan sebanyak $\pm 1 \mathrm{~kg}$ disimpan dalam kantong plastik polyvinil untuk diproses di laboratorium. Selama pengambilan sampel, tanah diupayakan terhindar dari dedahan sinar matahari langsung.

Di Laboratorium, nematoda diekstraksi dari $300 \mathrm{cc}$ tanah menggunakan metode penyaringan dan sentrifugasi dengan larutan gula. Nematoda difiksasi dalam larutan Golden X sehingga nematoda berada dalam 3\% formalin (Gafur dan Swibawa, 2004). Sebelum difiksasi, nematoda dimatikan pada suhu $50-60^{\circ} \mathrm{C}$, selanjutnya volume suspensi nematoda dibuat menjadi $10 \mathrm{ml}$ dengan memipetnya secara hati-hati. Penghitungan dengan bantuan handtally counter untuk menentukan kelimpahan absolut seluruh nematoda tiap sampel dilakukan di bawah mikroskop stereo binokuler pada perbesaran 40-60 kali. Nematoda dihitung dari $\pm 3 \mathrm{ml}$ suspensi nematoda dalam cawan petri bergaris yang dilakukan beberapa kali sampai seluruh suspensi habis. Preparat semipermanen dibuat untuk identifikasi nematoda di bawah mikroskop majemuk pada perbesaran 100-600 kali. Preparat dibuat 
I G. Swibawa dkk: Penerapan Sistem Olah Tanah dan Pemulsaan Pada Tebu untuk Pengendalian Nematoda

dengan mengait satu per satu nematoda, kemudian diletakkan pada gelas objek yang diberi setetes larutan gonden X, kemudian ditutup dengan cover glass. Satu preparat berisi sebanyak 10 - 15 individu nematoda yang diambil secara acak. Indentifikasi sampai tingkat takson genus dilakukan terhadap 100 nematoda dari setiap sampel berdasarkan ciri-ciri morfologi dengan pedoman kunci identifikasi bergambar Goodey, (1963); Mai and Lyon, (1975) dan referensi lain yang relevan. Jumlah suatu genus nematoda yang terdapat dari 100 nematoda yang diidentifikasi dinyatakan sebagai kelimpahan relatif genus.

Peubah yang diamati meliputi kelimpahan nematoda dan prominence value genus. Kelimpahan nematoda meliputi kelimpahan seluruh nematoda, kelimpahan relatif dan kelimpahan absolut tiap genus nematoda. Kelimpahan absolut (KA) genus nematoda adalah kelimpahan relatif genus dikalikan kelimpahan seluruh nematoda. Prominence value (PV) digunakan untuk menetapkan genus nematoda yang dominan, yang dihitung menggunakan formula sebagai berikut (Beals, 1960 cit. Norton, 1978).

Prominence Value $(\mathrm{PV})=\mathrm{KA} \times \sqrt{\mathrm{FA}}$

Frekuensi Absolut $(\mathrm{FA})=$

Untuk mengetahui pengaruh olah tanah dan pemulsaan, kelimpahan absolut tiga genus nematoda parasit tumbuhan paling dominan dianalisis ragam dengan Uji F, pemisahan nilai tengah dengan uji BNT, semua uji statistik menggunakan taraf nyata $5 \%$.

\section{HASIL DAN PEMBAHASAN}

\section{Prominence Value Genus Nematoda}

Dari plot percobaan pada pertanaman tebu ratoon II berumur 9 ditemukan 11 genus nematoda parasit tumbuhan dan 7 genus nematoda hidup bebas. Dari seluruh nematoda parasit tumbuhan yang ditemukan, Hoplolaimus, Xiphinema, dan Hemicriconemoides secara berurutan merupakan tiga genus nematoda parasit tumbuhan paling dominan yang dinyatakan dengan prominance value (PV) (Tabel 2). Pada Tabel 2 dapat dilihat bahwa PV Hoplolaimus paling tinggi $(P V=279,0)$ dengan kelimpahan aboslut $(\mathrm{KA})=279,0$ indiv. $300 \mathrm{cc} \operatorname{tanah}^{-1}$, sementara Xiphinema dan Hemicriconemoides secara berurutan memiliki PV pada urutan ke dua dan ke tiga yaitu masing-masing 32,0,4 dan 29,1 dengan KA masing-masing 32,9 dan 32,5 indiv. 300 $\mathrm{cc} \mathrm{tanah}^{-1}$. Nilai frekuensi absolut (FA) dapat digunakan untuk menilai intensitas temuan genus nematoda pada suatu lahan. Berdasarkan nilai FA, Hoplolaimus dapat ditemukan pada seluruh petak percobaan $(\mathrm{FA}=100 \%)$, sementara Xiphinema dan Hemicriconemoides ditemukan pada masing-masing 95 dan 80 persen petak percobaan $(\mathrm{FA}=95 \%$ dan $80 \%)$.

Banyak genus nematoda parasit tumbuhan berasosiasi dengan pertanaman tebu. Cadet and Spaull (2005) mencatat 13 genus nematoda yang sering ditemukan pada pertanaman tebu di berbagai negara. Dari semua genus tersebut, Pratylenchus dan Helicotylenchus adalah dua genus yang frekuensi temuannya tinggi di hampir seluruh negara, sementara Hoplolaimus dan Xiphinema frekuensi temuannya tinggi di Burkini Faso, India, Malaysia, dan Filipina. Handoyo (et al., 1980 cit. Spaull and Cadet, 1995) melaporkan bahwa Hoplolaimus ditemukan pada pertanaman tebu di Jawa, walaupun frekuensinya rendah; nematoda yang sering ditemukan di Jawa adalah Pratylenchus, Helicotylenchus, 
Meloidogyne, dan Criconematids. Hasil penelitian ini mengindikasikan bahwa komunitas nematoda parasit tumbuhan yang berasosiasi dengan pertanaman tebu di PT GMP didominasi Hoplolaimus, bukan Pratylenchus seperti di Jawa ataupun negara lain. Hasil pengamatan dalam penelitian ini menunjukkan bahwa kelimpahan absolut Pratylenchus hanya 2 indiv. $300 \mathrm{cc} \operatorname{tanah}^{-1}$ dengan frekuensi absolut $20 \%$.

Selain nematoda parasit tumbuhan, pada plot percobaan juga ditemukan nematoda yang hidup bebas. Nematoda hidup bebas memegang peran penting dalam ekosistem pertanian karena bersifat menguntungkan (Wardle, 2002). Dari 7 genus nematoda hidup bebas yang ditemukan dalam penelitian ini, Iotonchus dan Rhabditis merupakan dua genus yang memiliki PV paling tinggi. Iotonchus dan Rhabditis masing-masing adalah nematoda predator dan pemakan bakteri. Dengan nilai prominence tinggi dan frekuensi aboslut tinggi yaitu $\mathrm{FA}=85 \%$ untuk Iotonchus dan $\mathrm{FA}=45 \%$ untuk Rhabditis (Tabel 1), maka kedua nematoda ini dapat berarti positif bagi lahan pertanaman tebu di PT GMP.

Tabel 1. Kelimpahan aboslut, frekuensi absolut dan prominence value (PV) genus nematoda pada pertanaman tebu di PT GMP

\begin{tabular}{|c|c|c|c|c|}
\hline No & Nama Genus & $\begin{array}{c}\text { KA (indiv. } 300 \mathrm{cc} \\
\left.\operatorname{tanah}^{-1}\right)\end{array}$ & FA $(\%)$ & PV \\
\hline $\mathrm{t}$ & Nematoda Parasit Tumbuhan & & & \\
\hline 1 & Hoplolaimus & 279,0 & 100,0 & 279,0 \\
\hline 2 & Xiphinema & 32,9 & 95,0 & 32,0 \\
\hline 3 & Hemicriconemoides & 32,5 & 80,0 & 29,1 \\
\hline 4 & Criconemella & 11,5 & 20,0 & 5,1 \\
\hline 5 & Tylenchus & 4,1 & 20,0 & 1,8 \\
\hline 6 & Tylenchochynchus & 2,2 & 35,0 & 1,3 \\
\hline 7 & Pratylenchus & 2,2 & 20,0 & 1,0 \\
\hline 8 & Radopholus & 1,0 & 15,0 & 0,4 \\
\hline 9 & Tylodorus & 1,1 & 5,0 & 0,3 \\
\hline 10 & Trichodorus & 0,3 & 5,0 & 0,1 \\
\hline 11 & Longidorus & 0,1 & 5,0 & 0,0 \\
\hline & Nematoda Hidup Bebas & & & \\
\hline 12 & Iotonchus & 13,8 & 85,0 & 12,8 \\
\hline 13 & Rhabditis & 11,3 & 45,0 & 7,6 \\
\hline 14 & Aphelenchus & 4,2 & 60,0 & 3,3 \\
\hline 15 & Mononchus & 2,2 & 25,0 & 1,1 \\
\hline 16 & Dorylaimus & 1,1 & 5,0 & 0,2 \\
\hline 17 & Pelodera & 0,8 & 5,0 & 0,2 \\
\hline 18 & Sporonchulus & 0,2 & 5,0 & 0,0 \\
\hline
\end{tabular}

Keterangan: KA = Kelimpahan Absolut; FA = Frekuensi Absolut; PV = Prominence Value

\section{Pengaruh Sistem Olah Tanah dan Pemulsaan}

Pengaruh sistem olah tanah dan pemulsaan diuji terhadap kelimpahan absolut tiga genus nematoda parasit tumbuhan yang dominan yaitu Hoplolaimus, Xiphinema, dan Hemicriconemoides. Pengaruh sistem olah tanah, pemulsaan dan interaksinya terhadap ketiga nematoda parsit tumbuhan yang dominan bervariasi. Analisis ragam menunjukkan bahwa sistem olah tanah berpengaruh nyata ( $\mathrm{P}$ $<0,05)$ terhadap Xiphinema, tetapi tidak terhadap Hoplolaimus dan Hemicriconemoides. Sementara itu, pemulsaan berpengaruh nyata terhadap Hemicriconemoides, tetapi tidak terhadap dua genus lainnya. Interaksi antara sistem olah tanah dengan pemulsaan berpengaruh sangat nyata $(\mathrm{P}<0,01)$ terhadap Hoplolaimus (Tabel 2). 
I G. Swibawa dkk: Penerapan Sistem Olah Tanah dan Pemulsaan Pada Tebu untuk Pengendalian Nematoda

Tabel 2. Nilai $F$ hitung analisis ragam pengaruh sistem olah tanah dan pemulsaan terhadap kelimpahan tiga genus nematoda parasit tumbuhan yang dominan

\begin{tabular}{llll}
\hline Perlakuan & Genus Nematoda & & \\
\cline { 2 - 4 } & Hoplolaimus & Xiphinema & Hemicriconemoides \\
\hline Olah Tanah & $1.15^{\text {tn }}$ & $5,33^{*}$ & $2,60^{\text {tn }}$ \\
Pemulsaan & $0.63^{\text {tn }}$ & $0,16^{\text {tn }}$ & $5,26^{*}$ \\
Olah Tanah $\times$ Pemulsaan & $20.69^{* *}$ & $0,52^{\text {tn }}$ & $3,16^{\text {tn }}$ \\
\hline
\end{tabular}

Keterangan : ** $=$ sangat nyata $(\mathrm{P} \leq 0.01) ; *$ nyata $(\mathrm{P} \leq 0,05)$ dan $\mathrm{tn}=$ tidak nyata $(\mathrm{P}>0.05)$.

Kelimpahan nematoda Xiphinema dipengaruhi oleh sistem olah tanah tetapi tidak dipengaruhi oleh perlakuan lainnya. Pada lahan pertanaman tebu yang diolah secara intensif kelimpahan Xiphinema mencapai 45,18 indiv. $300 \mathrm{cc} \mathrm{tanah}^{-1}$, nyata $(\mathrm{P}<0,05)$ lebih tinggi daripada kelimpahan nematoda ini pada lahan tanpa olah tanah, yaitu 20,56 indiv. $300 \mathrm{cc} \operatorname{tanah}^{-1}$ (Tabel 3).

Tabel 3. Kelimpahan Xiphinema pada pertanaman tebu ratoon-II umur 9 bulan dengan sistem olah tanah yang berbeda

\begin{tabular}{lc}
\hline Sistem Olah Tanah & $\begin{array}{c}\text { Kelimpahan Xiphinema } \\
(\text { Indiv. 300cc tanah }\end{array}$ \\
\hline Olah Tanah Intensif (OTI) & $45.18 \mathrm{a}$ \\
Tanpa Olah Tanah (TOT) & $20.56 \mathrm{~b}$ \\
\hline
\end{tabular}

Keterangan : Angka yang diberi huruf sama tidak berbeda menurut uji BNT $(\mathrm{g}=0,05)$.

Kelimpahan nematoda Hemicriconemoides dipengaruhi oleh pemulsaan, tetapi tidak dipengaruhi oleh perlakukan lainnya. Kelimpahan Hemicriconemoides pada lahan pertanaman tebu yang tidak diberi mulsa mencapai 46,14 indiv. $300 \mathrm{cc} \operatorname{tanah}^{-1}$, nyata $(\mathrm{P}<0,05)$ lebih tinggi daripada kelimpahan nematoda ini pada lahan yang diberi mulsa yaitu 18,88 indiv. $300 \mathrm{cc} \mathrm{tanah}^{-1}$ (Tabel 4).

Tabel 4. Kelimpahan Hemicriconemoides pada pertanaman tebu ratoon-II umur 9 bulan dengan sistem olah tanah yang berbeda

\begin{tabular}{lc}
\hline Sistem Pemulsaan & Kelimpahan Hemicriconemoides (Indiv. 300 $\mathrm{cc} \mathrm{tanah}^{-1}$ ) \\
\hline Dengan mulsa bagas 80 ton ha $^{-1}$ & $18.88 \mathrm{~b}$ \\
Tanpa diberi mulsa & $46.14 \mathrm{a}$ \\
\hline
\end{tabular}

Keterangan : Angka yang diberi huruf sama tidak berbeda menurut uji BNT $(\mathrm{g}=0,05)$.

Pada Gambar 1 tampak bahwa kelimpahan Hoplolaimus dipengaruhi oleh interaksi sistem olah tanah dengan pemulsaan. Pada sistem tanpa olah tanah, pemberian mulsa secara nyata $(\mathrm{P}<0,05)$ menurunkan kelimpahan nematoda ini. Pada sistem tanpa olah tanah tanpa mulsa kelimpahan Hoplolaimus mencapai 346,96 indiv. 300 $\mathrm{cc} \mathrm{tanah}^{-1}$, lebih tinggi daripada kelimpahan nematoda ini pada perlakuan tanpa olah tanah dengan mulsa yaitu 241,20 indiv $300 \mathrm{cc} \operatorname{tanah}^{-1}$. Hal yang sebaliknya terjadi pada sistem olah tanah intensif, pada sistem olah tanah ini, pemberian mulsa secara nyata meningkatkan kelimpahan nematoda ini, yaitu dari 188,61 meningkat menjadi 339,11 indiv.300 cc $\operatorname{tanah}^{-1}$. Dari data ini dapat diketahui bahwa pemberian mulsa berperan penting dalam pengendalian nematoda Hoplolaimus pada sistem tanpa olah tanah. Apabila sistem olah tanah intensif yang diterapkan, maka tanpa pemberian mulsa akan dapat menurunkan kelimpahan nematoda, sebaliknya apabila sistem tanpa olah tanah yang diterapkan maka pemberian mulsalah yang dapat menurunkan kelimpahan nematoda. 


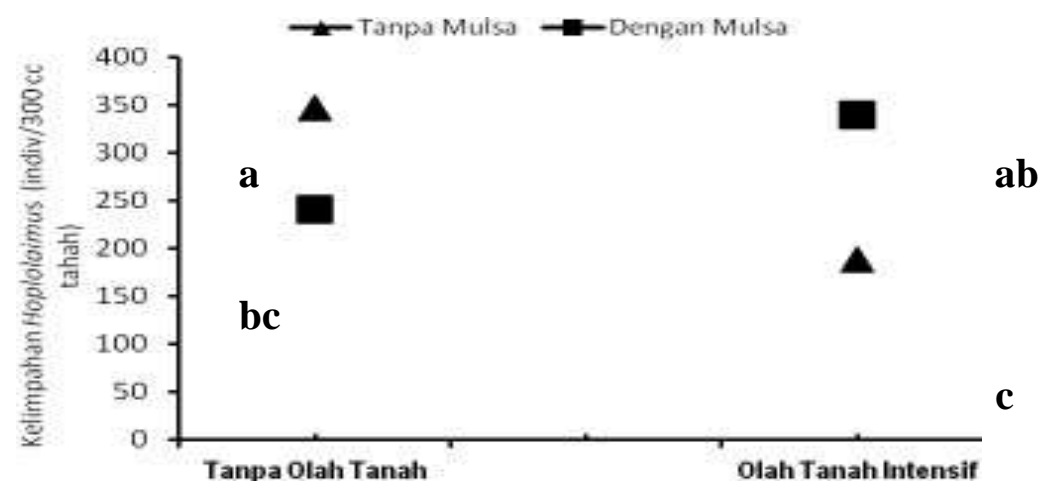

Gambar 1. Kelimpahan Hoplolaimus pada pertanaman tebu ratoon-II umur 9 bulan dengan perlakuan olah tanah dan pemulsaan; label dengan huruf sama tidak berbeda menurut uji BNT ( $\mathrm{g}$ $=0,05$ ).

Hasil penelitian ini menunjukkan bahwa sistem olah tanah berpengaruh terhadap kelimpahan Xiphinema tetapi tidak terhadap dua genus dominan lainnya. Dengan kata lain, pengaruh sistem olah tanah terhadap kelimpahan nematoda parasit tumbuhan yang dominan bervariasi. Data ini sejalan dengan hasil beberapa penelitian sebelumnya yang menunjukkan pengaruh sistem olah tanah terhadap kelimpahan nematoda adalah bervariasi. Hendrix et al. (1986) ; Okada and Harada (2007) melaporkan bahwa pengaruh sistem olah tanah terhadap kelompok makan nematoda bervariasi. Pengaruh sistem olah tanah terhadap kelimpahan nematoda parasit tumbuhan bervariasi menurut kedalaman tanah dilaporkan oleh Xueckun at al. (2010), sementara Baird and Bernard (1984) melaporkan pengaruh sistem olah tanah terhadap kelimpahan nematoda parasit tumbuhan bervariasi menurut waktu.

Walaupun nematoda sangat peka terhadap gangguan lingkungan tanah (Freckman and Ettema, 1993), namun hasil penelitian ini dan penelitian lain sebelumnya menunjukkan bahwa pengaruh sistem olah tanah (TOT vs OTI) berbeda antar genus dan kelompok makan nematoda. Hal ini diduga karena setiap genus atau kelompok makan memiliki daya tahan yang berbeda terhadap tingkat gangguan lingkungan tanah. Salah satu faktor intrinsik yang mungkin menyebabkan variasi daya tahan nematoda terhadap gangguan lingkungn adalah variasi ukuran tubuh genus atau kelompok makan. Mills and Adl (2011) melaporkan ukuran tubuh nematoda Dorylaimida meningkat ketika lahan mendapat gangguan secara intensif. Dalam penelitian ini kelimpahan Xiphinema lebih tinggi pada lahan dengan sistem OTI yang lebih terganggu daripada sistem TOT, mungkin karena nematoda tersebut tubuhnya besar (c-p = 5), tergolong strategi K dari famili Longidoridae (Bonger and Bonger, 1998) maka lebih tahan terhadap gangguan lingkungan tanah.

Hasil penelitian ini menunjukkan bahwa pemberian mulsa bagasse pada pertanaman tebu dapat menurunkan kelimpahan Hemicriconemoides pada semua perlakuan sistem olah tanah (Tabel 4), sedangkan untuk Hoplolaimus pemberian mulsa hanya berlaku pada lahan tanpa olah tanah (Gambar 1). Pemberian mulsa dapat penurunan kelimpahan nematoda parasit tumbuhan, mungkin karena mulsa bagasse memicu kondisi penekan (suppression) nematoda parasit tumbuhan. Stirling et al. (2003) melaporkan bahwa pemberian bahan organik mengandung $\mathrm{C} / \mathrm{N}$ rasio tinggi seperti bagasse dapat menurunkan populasi nematoda peluka akar (Pratylenchus) pada tanaman tebu. Pemberian mulsa organik ini mamacu berbagai jenis jamur dan nematoda omnivora menjadi dominan dan sebagai suppression bagi nematoda parasit tumbuhan. Untuk mengendalikan Hoplolimus, pemberian mulsa hanya efektif pada sistem tanpa olah tanah, sebaliknya pemberian mulsa pada sistem olah tanah intensif justeru meningkatkan populasi nematoda (Gambar 1). Pemberian mulsa pada sistem olah 
I G. Swibawa dkk: Penerapan Sistem Olah Tanah dan Pemulsaan Pada Tebu untuk Pengendalian Nematoda

tanah intensif yang meningkatkan Hoplolaimus mungkin karena mulsa dapat menjaga kondisi kelembaban tanah tetap stabil yang cocok bagi perkembangannya dan mulsa tidak cukup efektif sebagai pemicu kondisi lingkungan suppression. Data ini mengindikasikan bahwa penerapan sistem tanpa olah tanah untuk pengendalian nematoda parasit tumbuhan akan lebih efektif apabila dikombinasikan dengan pemulsaan. Dalam kondisi lahan dengan gangguan minimum seperti pada sistem tanpa olah tanah, pemberian mulsa dengan $\mathrm{C} / \mathrm{N}$ rasio tinggi misalnya bagasse, lebih efektif dalam menciptakan kondisi lingkungan suppression karena memacu berkembangnya biota antagonis nematoda parasit tumbuhan.

\section{KESIMPULAN}

Dari hasil penelitian ini dapat disimpulkan bahwa (1) ppada plot percobaan ertanaman tebu di PT GMP ditemukan 11 genus nematoda parasit tumbuhan dan 7 genus nematoda hidup bebas. Tiga genus nematoda parasit tumbuhan yang dominan adalah Hoplolaimus, Xiphinema dan Hemicriconemoides; (2) sistem olah tanah pada pertanaman tebu mempengaruhi kelimpahan nematoda parasit tumbuhan dan sistem tanpa olah tanah dapat menurunkan kelimpahan Xiphinema; dan (3) pemberian mulsa bagasse pada lahan pertanaman tebu mempengaruhi kelimpahan nematoda parasit tumbuhan, pemberian mulsa bagasse 80 ton ha ${ }^{-1}$ efektif menurunkan kelimpahan nematoda Hemicriconemoides, sementara itu, pemberian mulsa untuk menurunkan kelimpahan nematoda Hoplolaimus, lebih efektif pada sistem tanpa olah tanah daripada sistem olah tanah intensif.

\section{SANWACANA}

Dalam kesempatan ini penulis mengucapkan terima kasih kepada para peneliti "Proyek Penelitian Soil Rahabitation" kerjasama Unila-YNU-GMP yang difasilitasi PT GMP yang telah memberikan ijin kepada penulis untuk melakukan pengamatan pada plot percobaannya.

\section{DAFTAR PUSTAKA}

Baird, S. M. and E.C. Bernard. 1984. Nematode Population and Community Dynamics in SoybeanWheat Cropping and Tillage Regimes. Journal of Nematology 16 (4) : 379-386.

Bond, J.P., E.C. McGawely and J.W. Hoy. 2004. The impact of nematodes on sugarcane cultivars. NEMATROPICA (34) 2: 235-243

Bonger T. and M. Bonger. 1998. Functional diversity of nemtodes. Applied Soil Ecology $10: 239$ 251.

Cadet, P. and Spaull, V. W. 2005. Nematode Parasities of Sugarcane. Di dalam: M. Luc, R.A Sikora and J. Bridge (Eds.). Plant Parasitic Nematodes in Subtropical and Tropical Agriculture. $2^{\text {nd }}$ Ed. CAB International. P. 645-676. 
Jurnal Penelitian Pertanian Terapan

Chirchir, A., J. Kimenju and F Olubayo. 2008. Eccurcence, abundance, and distribution of plant parasitic nematodes assosiated with sugarcane in Western Kenya. Proc. S. Afr. Sug. Technol. Ass. 81: 352-354.

Freckman, D.W. \& C.H. Ettema, 1993. Assessing nematode communities in agroecosystems of varying human intervention. Agriculture Ecosystem and Environment 45: 239-261.

Gafur, A. \& I G. Swibawa. 2004. Methods in Nematodes and Soil Microbe Research for Belowground Biodiversity Assessment. Di dalam: F.X Susilo, A. Gafur, M. Utomo, R. Evizal, S. Murwani, I G. Swibawa, (Eds.). Conservation and Sustainable Management of Below-Ground Biodiversity in Indonesia. Universitas Lampung. P. 117-123.

Goodey, J.B., 1963. Soil and freshwater nematodes. Mathuen \& CO LTD, London., John Wiley \& Sons, INC, New York.

Hasanah, U., I G. Swibawa dan T.N. Aeny , 2014. Pengaruh pengolahan tanah dan pemulsaan terhadap keragaman dan kelimpahan nematoda parasit tumbuhan pada periode tanaman ratoon-I di perkebunan PT Gunung Madu Plantation. J. Agrotek Tropika 2 (1) : 108-114.

Hendrix, P.F., R.W. Parmelee, D.A. Crossley, Jr., D.C. Coleman, E.P. Odum, and P.M. Groffman. 1986. Detritus Food Webs in Conventional and No-Tillage Agroecosystems. BioScience, 36 ( 6) : 374-380

Kalshoven, L.G.E. 1981. The pest of crops in Indonesia. Revised and translated by P.A. Van der Laan. PT Ichtiar Baru-Van Hoeve- Jakarta.

Mai, W.F., \& H.H Lyon. 1975. Pictorial key to genera of plant-parasitic nematodes. Comstock Publishing Associates, Cornell University Press. USA.

Milss, A.A.S. and M.S. Adl. 2011. Changes in nematode abundances and body length in response to management intensive grazing in a low-input temperate pasture. Soil Biology and Biochemistry 43: 150-158.

Norton, D.C. 1978. Ecology of Plant Parasitic Nematodes. John Willey and Sons, New York, Chichester, Brisbane, and Toronto.

Okada, $\mathrm{H}$ and H. Harada. 2007. Effect of tillage and fertilizer on nematode communities in a Japanese soybean field. Applied Soil Ecology 35 : 582-598.

Prakash, R., D.K. Singh and M. Kumar. 2009. Collection and distribution frequency of plant parasitic nematodes associated with sugarcane in Utar Pradesh a field study. Biological Forum - An International Journal, 1(1) : 85-88

Saechu, M. 2009. Optimasi pemanfaatan energi ampas di pabrik gula. Jurnal Teknik Kimia 4 (1) : 274280

Shoko, M.D. and M. Zou. 2009. Nematode diversity in a soybean-sugarcane production system in a semi-arid region of Zimbabwe. Journal of Entomology and Nematology 1 (2) : 025-028

Sibagariang, M.T. I G. Swibawa dan Solikhin. 2014. Pengaruh reduksi olah tanah dan pemulsaan terhadap kelimpahan nematoda parasit tumbuhan pada pertanaman tebu berumur 11 bulan. J. Agrotek Tropika 2 (1) ; 130-133. 
I G. Swibawa dkk: Penerapan Sistem Olah Tanah dan Pemulsaan Pada Tebu untuk Pengendalian Nematoda

Spaull, V. W. dan P. Cadet. 1995. Nematoda Parasitik Pada Tanaman Tebu. Di dalam: M. Luc., R.A. Sikora, and J. Bridge (Eds.). Plant Parasiticts Nemtodes in Subtropical and Tropical Agriculture ditejemahkan oleh Supratoyo. Nematoda Parasitik Tumbuhan di Pertanian Tropik dan Subtropik. Gadjah Mada University Press. Yogyakarta. P. 621-664

Spaull, V.W. and P. Cadet. 2003. Impact of nematodes on sugarcane and the benefit of tolerant varieties. Proc. S. Afr. Sug. Technol. Ass. 77: 230-238.

Steven, A., S. Sunday and D. Fisayo, 2014. Biodiversity of plant parasitic nematodes of sugarcane in Bacita, Nigeria. Journal of Entomology and Nematology 6 (6) : 71-79.

Stirling, G.R., E.J. Wilson, A.M. Stirling, C.E. Pankhurst, P.W. Moody, P. W., and M.J. Bell. 2003. Organic amendments enhance biological suppression of plant parasitic nematodes in sugarcane soils. Conference of the Australian Society of Sugar Cane Technologists 2003. Online on www.assct.com.au/media/ [13 Desember 2014].

Susilo, F.X. and A. Karyanto. 2005. Methods for assesment of below-ground biodiversity in Indonesia. Universitas Lampung, Bandar Lampung.

Swibawa, I G. 2010. Komunitas nematoda tanah pada lahan jagung setelah 23 tahun penerapan sistem budidaya tanpa olah tanah secara terus-menerus. Di dalam: Prosiding Seminar Nasional Keragaman Hayati Tanah-I. Bandar Lampung. P. 147-161.

Utomo, M., A. Niswati, Deriyati, M.R. Wati, E.F. Raguan and S. Syarif. 2010. Earthworm and Soil Carbon Sequestration after Twenty One Years of Continuous No-tillage Corn-Legume Rotation in Indonesia. JIFS. $7: 51-58$.

Wardle, D.A. 2002. Communities and Ecosystems: Lingking The Aboveground and Belowground Component. Princeton Uni. Press. UK.

Xuekun, H., H. Ning, Z. Xiaoke, L. Lei, and Z. Ruichang. 2010. Vertical Distribution of Soil Nematode Communities under Different Tillage Systems in Lower Reaches of Liaohe River. Chin. Geogra. Sci. 20 (2): $106-111$. 